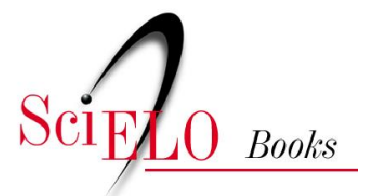

\title{
Anexo metodológico
}

\author{
Juarez Rubens Brandão Lopes
}

LOPES, JRB. Brasil, 1989: um estudo sócio-econômico da indigência e da pobreza [online]. Rio de Janeiro: Centro Edelstein de Pesquisas Sociais, 2008. Anexo metodológico. pp. 59-63. ISBN: 978-8599662-75-5. Available from SciELO Books $<\underline{\text { http://books.scielo.org }>\text {. }}$

\section{(1) $(0)$}

All the contents of this chapter, except where otherwise noted, is licensed under a Creative Commons Attribution-Non Commercial-ShareAlike 3.0 Unported.

Todo o conteúdo deste capítulo, exceto quando houver ressalva, é publicado sob a licença Creative Commons Atribuição Uso Não Comercial - Partilha nos Mesmos Termos 3.0 Não adaptada.

Todo el contenido de este capítulo, excepto donde se indique lo contrario, está bajo licencia de la licencia Creative Commons Reconocimento-NoComercial-CompartirIgual 3.0 Unported. 


\section{Anexo metodológico}

\section{As linhas de indigência e de pobreza}

Nesse estudo da pobreza no Brasil urbano e nas suas regiões, utilizou-se, como já foi assinalado, o critério de renda per capita, enfocando-se as linhas de indigência e pobreza. Noutras palavras, para se distinguir domicílios pobres de não pobres, e dentro do primeiro grupo, domicílios indigentes de não indigentes, foram adotados parâmetros de valor de renda domiciliar per capita, que correspondem a níveis de consumo compatíveis com o atendimento de necessidades básicas, seja só ao das alimentares (linha de indigência), seja ao total das necessidades básicas, alimentares e não alimentares (linha de pobreza).

$\mathrm{O}$ meu ponto de partida para a determinação dessas linhas de indigência e de pobreza, para as regiões urbanas brasileiras, foram as linhas traçadas por Sonia Rocha (1991, p.36) para as regiões metropolitanas. Os dados básicos que Sonia Rocha usou foram os do Estudo Nacional de Despesa Familiar - ENDEF, de 1974/75. Algumas citações do trabalho de Sonia Rocha (todas constantes da p.35) permitem especificar os seus procedimentos. Ela nos informa:

"Tendo em vista as reconhecidas diferenças da estrutura de consumo entre regiões metropolitanas, optou-se por tomar como base as 'cestas' verificadas em cada uma delas para as camadas de baixa renda". Isso foi feito, utilizando-se "as estruturas de consumo alimentar do $2^{\circ}$ decil inferior da distribuição de despesas correntes do ENDEF e o coeficiente de Engel do 40 decil" "39. "Aos diferentes itens de consumo foram associados preços [usando os índices de preços ao consumidor do IBGE] referentes a cada ano e a cada região metropolitana, com o objetivo de levar em conta explicitamente nos valores das linhas de pobreza as evoluções diferenciadas do custo de vida que ocorrem localmente".

Calculei os valores das linhas de indigência e pobreza para as populações urbanas de cada região, a partir dos valores calculados por Sonia Rocha para as metrópoles da região. Vejamos como isso foi feito. Eu

\footnotetext{
${ }^{39}$ Informações mais detalhadas da sua metodologia são encontradas em Rocha (1988).
} 
tinha, de início, além dos valores das linhas para as metrópoles, (a) os custos das cestas de alimentos e das cestas totais, constantes da pesquisa do ENDEF de 74/75, para as metrópoles da região e para as áreas urbanas não metropolitanas dessa região (estes dados constam de Fava, 1984, p.102) e (b) estimativas das populações das metrópoles e das áreas urbanas não metropolitanas em 1989. Para o cálculo das linhas para a região urbana como um todo, utilizei médias ponderadas, em que a ponderação foi dada pelas estimativas de população em 1989, e simples regras de três.

Preciso sublinhar um dos pressupostos dos meus cálculos. Sonia Rocha usa para cada metrópole a sua estrutura de consumo dada pelo ENDEF de 1974/75 e usa o índice de preços dessa metrópole para atualizar os preços dos componentes da cesta para cada ano da década de oitenta, no caso que me interessa, para 1989. Assim, partir das linhas de pobreza que ela calcula para as regiões metropolitanas, a fim de se calcular as linhas para as populações urbanas como um todo, do modo como eu fiz, significa pressupor que se mantêm, hoje, as diferenças de custo de vida que existiam no passado, entre as áreas metropolitanas e as urbanas não metropolitanas da região. Isto, porém, não deve ter ocorrido nas duas últimas décadas. Supondo-se que estas diferenças de custo de vida tenham diminuído, o que parece mais provável, os meus cálculos estariam sub-estimando as linhas de pobreza para o conjunto das populações urbanas e sub-estimando, assim, as taxas de pobreza ${ }^{40}$.

Uma última observação. Não calculamos linhas de indigência e de pobreza para o Brasil urbano como um todo. As linhas para as várias regiões urbanas servem para separar em cada uma delas, indigentes, pobres não indigentes e não pobres. A soma desses vários componentes populacionais de todas as regiões nos dão o conjunto de indigentes, pobres não indigentes e não pobres para todo o Brasil.

\section{Membros do domicílio}

Como nas PNADs, na PNSN inclui-se entre os moradores do domicílio, além de membros da família no sentido próprio (unidade onde se

\footnotetext{
${ }^{40}$ Não existindo no Brasil índices de preços para áreas não metropolitanas, não há como corrigir-se esta distorção.
}

juntam rendimentos e o "consumo" ocorre em comum), outras pessoas nas condições de 'pensionista', 'empregado doméstico' e 'parente de empregado doméstico'.

Para a grande maioria dos indicadores usados neste estudo, excluir ou não dos domicílios essas pessoas que não pertencem à família, altera muito pouco os resultados. Retirei assim essas categorias de pessoas apenas em alguns casos em que, se isso não fosse feito, os dados seriam mais afetados, quais sejam no de indicadores baseados em rendimentos (tipos de renda da família por exemplo), na estrutura etária, na condição de atividade (por exemplo no caso das proporções de domicílios com $\mathrm{O}$ ocupados) e nos tipos de estruturas familiares.

\section{O indicador de necessidades básicas insatisfeitas}

O indicador da não satisfação das necessidades básicas que foi utilizado é um conjunto de seis variáveis, onde basta uma delas indicar uma situação má, para o domicílio ser classificado como NBI (os demais sendo NBS).

As variáveis que indicam a existência de necessidades básicas insatisfeitas foram as seguintes:

1) densidade de pessoas por dormitório maior do que 3,5 ;

2) o domicílio ser do tipo 'rústico';

3) o seu abastecimento de água ser de 'outra forma' (não ser da rede geral, de poço ou de nascente) e não ter canalização interna;

4) não ter esgotamento sanitário;

5) não ter vaso sanitário; e

6) possuir crianças de 7 a 11 anos que não freqüentam escola.

Os componentes do indicador foram deliberadamente escolhidos a fim de se ter situações que, nas condições sócio-econômica brasileiras, possam ser consideradas muito más, extremas mesmo, qualquer que seja a região. 


\section{As ocupações 'pobres'}

Num estudo da região metropolitana do Rio de Janeiro, Figueiredo et al. (1990), analisando as remunerações das ocupações, desenvolveram uma tipologia de ocupações: ocupações 'pauperizadas', 'ocupações com renda variável', ocupações concentradas nas classes de renda superior (mas que também podem registrar baixas rendas), e ocupações de 'alta remuneração assegurada'. Especifiquemos, um pouco mais, os procedimentos usados para identificar o grupo de trinta e quatro categorias de ocupações pauperizadas, que usei no presente estudo (ver Tabela 9) sob a denominação de ocupações 'pobres'.

Os autores inicialmente agregaram as 366 ocupações existentes no arquivo primário (dados da PNAD de 1987 para o Rio de Janeiro) em 108 categorias, agrupando "ocupações afins desde que tivessem frequiência muito reduzida (menor que 10 casos)". Dessas 108 categorias, incluiu-se entre as ocupações 'pobres' aquelas que tivessem majoritariamente (mais de $75 \%$ ) remuneração inferior ou igual a três salários mínimos ${ }^{41}$. Dessa operação resultaram 34 ocupações 'pobres'.

A rigor, eu deveria repetir este procedimento para cada uma das regiões urbanas deste estudo. Preferi, entretanto, fazer um exame preliminar da questão do grau de concentração em ocupações 'pobres', dos trabalhadores de domicílios em diversos níveis de pobreza/não pobreza, usando a lista dessas ocupações que resultou do estudo de Figueiredo et al.

A lista de ocupações definidas como 'pobres' é, portanto, a seguinte: recepcionistas; produtor agropecuário autônomo; trabalhador agropecuário /pesca; alfaiates /costureiras; outros trabalhadores do vestuário/ calçados; carpinteiros; lustradores/estofadores; montadores elétricos; reparadores TVrádio; Serventes pedreiros; pedreiros; pintores /caiadores; padeiros; outros trabalhadores artesanais alimentos; borracheiros /lapidadores; embaladores de mercadorias; vendedores; operadores de caixa; repos. /demonstr. mercadorias; feirantes; vendedores ambulantes; vendedores de jornais; empregadas domésticas; camareiras /cozinheiras; atendente de bar;

41 "Quatro ocupações que não correspondem exatamente a este limite foram introduzidas,
levantando-se em conta o alto grau de pobreza familiar: os carpinteiros, os pedreiros, os

levantando-se em conta o alto grau de pobreza familiar: os carpinteiros, os pedreiros, os
técnicos de conserto de TV/rádio e os lixeiros" (p.29). cabeleireiros /manicures; lavadeiras /passadeiras; porteiros /ascensoristas; vigias; serventes; contínuos; guardas vigias particulares; lixeiros; trabalhadores braçais. 